\title{
Term limits and political budget cycles at the local level: evidence from a young democracy
}

\author{
Fabio Alvim Klein (EACH - USP) \\ Sergio Naruhiko Sakurai (Departament of Economics - FEA-RP - USP)
}

July 16, 2014

\begin{abstract}
The existing empirical literature on political budget cycles (PBCs) has generally ignored the effects of term limitations on fiscal opportunism. In this paper, we explore the different electoral incentives faced by first term mayors who are eligible for reelection and second term mayors who are legally banned to stand for another term in office. Our results point to significant fiscal differences between both types of mayors in Brazil. During elections, first term mayors decrease revenues from own local taxation and change their budget composition by moving from current expenditures towards capital related ones, while budget balances and total expenditures remain unchanged. These findings are consistent with recently developed signalling models of PBC and with the conditional political budget cycles literature, where incumbents aiming at maximizing their reelection chances subject to institutional restrictions on fiscal deficits change the composition of the budget in electoral years by providing more visible and targeted expenditures.
\end{abstract}

Key words: Term limits; Political budget cycles; Local government budget; Panel data

\begin{abstract}
A literatura sobre ciclos político-orçamentários (CPOs) tem geralmente ignorado os efeitos de limitações de mandato sobre o oportunismo fiscal dos políticos. Nesse artigo, exploramos os diferentes incentivos eleitorais presentes em prefeitos de primeiro mandato, que são elegíveis à reeleição, e prefeitos de segundo (último) mandato que estão legalmente impedidos de permanecer no cargo por mais um mandato. Nossos resultados mostram que esses dois tipos de prefeitos apresentam comportamentos fiscais distintos no Brasil. Durante as eleições, prefeitos de primeiro mandato reduzem a arrecadação com tributos locais e mudam a composição do gasto através de reduções em despesas correntes e aumentos em despesas de capital, mantendo inalterados o balanço orçamentário e o gasto total. Essas evidências são consistentes com teorias recentes de CPOs baseadas em modelos de sinalização de competência e com a literatura sobre ciclos políticos condicionados, onde governantes interessados em maximizar suas chances de reeleição sujeitos à restrições fiscais institucionais, alteram a composição do orçamento, privilegiando gastos mais visíveis e focalizados.
\end{abstract}

Palavras-chave: Limite de mandato; Ciclos político-orçamentários; Finanças públicas municipais; Dados em painel

JEL: H72, C23, D72

Área 5 - Economia do Setor Público 


\section{Introduction}

Since Nordhaus (1975) launched his model of political business cycle - in which an incumbent politician seeking reelection would behave opportunistically by promoting expansionary economic policies prior to elections - a large body of empirical work testing his theory has been produced over the last 30 years. Among the many political motivations driving political business cycles, perhaps the main one is the ambition of reelection (of a politician or party). Therefore, the legal and real possibility of an incumbent politician or party to be reelected is a necessary condition for the emergence of political business cycles. However, not all incumbents are eligible to run for reelection, and indeed, not all seek reelection. Most of the literature ignores this fact. This omission is critical, since incumbents who are not eligible for reelection should not, a priori, engage in opportunistic fiscal policy as a strategy to increase their reelection chances. As prescribed by Rogoff (1990) in his classical model of rational political budget cycles (PBCs), "The prospect of being able to run for reelection again in the future raises the temptation to distort fiscal policy, and thus tends to exacerbate the political budget cycle." (Rogoff (1990), p. 30).

How, then, do the fiscal strategies of politicians who are eligible for reelection differ from those who cannot stand for a subsequent mandate as elections draw close? In other words, does the possibility of reelection affect fiscal policy? If the theoretical predictions of opportunistic fiscal cycles are correct, one should expect more loose fiscal policies in the last years of a mandate (i.e. election years) for the group of first term politicians (who are eligible for reelection) than for the group of last term politicians (who are legally impeded from running for reelection). Surely, the assumption that first term incumbents are more inclined to behave opportunistically compared to those at their last term could be false if one considers that even last term incumbents still have incentives to behave opportunistically, for example, if they seek to secure the reelection of their parties or bolster their own political career once their permitted term expires. Moreover, it could be that last term incumbents would be inclined to generate higher deficits whenever transferring office to a political opponent, leaving an unfavourable fiscal environment for the following government.

The above arguments are very plausible and show how difficult it might be to empirically determine the driving forces behind fiscal opportunism. Those arguments suggest that what to expect empirically may not be clear-cut because of the different factors that potentially influence the behaviour of incumbents. Yet, if both first term and last term incumbents face - to a greater or lesser extent - electoral incentives to manipulate fiscal outcomes, it is reasonable to assume that observable differences in their fiscal behaviour, after one has adequately controlled for other relevant factors, may be explained by their different reelection conditions. In this sense, we posit that identifying incumbents as first or last term office holders is both feasible and meaningful for an appropriate empirical analysis of the opportunistic-type PBC.

The main purpose of this paper is to estimate the effect of term limitations on the fiscal strategies employed by Brazilian local governments, especially during election periods. Based on fiscal and electoral data of 3,393 Brazilian municipalities between 2001 and 2008, this paper provides evidence in support of the proposition that significant differences exist between the fiscal strategies employed by first term and second term mayors during elections. As elections draw near, first term mayors reduce local tax revenues and adjust their budget composition by moving from current towards capital-related expenditures. Interestingly, they do so without detriment to the budget balance. The findings of this paper are consistent with recently developed signalling models of PBC and with the conditional political budget cycles literature: in Brazil, first term mayors and reelection runners, while facing incentives to behave opportunistically, are at the same time subject to institutional restrictions on fiscal policy. As a consequence, mayors running for reelection change the composition of the budget in electoral years by increasing the types of expenditures which are more visible and presumably more appealing to voters (i.e. investments) while keeping a controlled fiscal balance. This regard for fiscal balance signals levels of competence or policy preferences to rational and 
heterogeneous voters who may (or may not) be averse to higher spending in general, but have a preference for targeted expenditures (Drazen \& Eslava (2010)).

Brazil is an interesting case study to test the opportunistic fiscal cycle at the local level for a number of reasons. First, Brazil has over 5,500 municipalities and almost 140 million voters, making it one of the biggest and most politically decentralized federalist countries in the world. Additionally, municipalities constitute the smaller electoral district in Brazil, being the main geographical unit where votes are cast in local, state and national elections - in this sense, much of the political game is played at the municipal level. Thirdly, municipalities are subject to a number of common constitutional rules, being comparable in a broad range of institutional features. Finally, using the terminology developed in the recent literature on political cycles (e.g. Brender \& Drazen (2005); Shi \& Svensson (2006)), Brazil can be classified as a young developing democracy. Following 20 years of military dictatorship (1964-1984), Brazilian voters have been getting adapted to the electoral process over the recent past, which should have reduced the scope for fiscal manipulations during elections. In fact, the Brazilian economy has recently undergone important institutional changes affecting electoral and fiscal policies, with potentially relevant impacts on political cycles. As the recent conditional political budget cycles literature suggests, the presence and magnitude of electoral fiscal cycles are conditioned on certain institutional, political and economic contexts (e.g. De Haan \& Klomp (2013a)).

The paper is structured as follows. Section II provides a brief literature review on political business cycles and term limitations, with a particular focus on fiscal policy. In section III, we present the Brazilian institutional setting, followed by a description of the data in section IV. In section $\mathrm{V}$ we describe the empirical methodology. The main results are analyzed in section VI, followed by concluding remarks in section VII.

\section{Literature review}

The literature on political business cycles has traditionally identified two sources of politically motivated economic cycles. In the opportunistic political cycles models, politicians utilise electoral periods as an opportunity to increase their reelection chances by promoting positive shocks to the economy in the period before elections 1 . In the partisan cycles models, business cycles are partially caused by changes in economic policy according to the different ideological positions of the elected parties $2^{2}$. In the present study, we are specifically interested in opportunistic cycles at the local level in Brazil and in how they relate to term limitations $3^{3}$.

In the last 20 years, the empirical literature on political budget cycles (PBCs) has generated a good range of findings and explanations about their nature and mechanics, promoting a rich discussion on the topic. For instance, many studies have confirmed the classical theoretical view of pre-electoral increases in deficits (Brender \& Drazen (2005); Shi \& Svensson (2006); Veiga \& Veiga (2007)), while others have only found increases in certain types of expenditures, but not in overall spending or deficits (Drazen \& Eslava (2010); Schneider (2010)). These later studies were aligned somewhat with the "voters as fiscal conservatives" concept (Brender (2003); Brender \& Drazen (2008); Peltzman (1992)), for which the median voter prefers less - rather than more - government spending and thus

\footnotetext{
${ }^{1}$ Important initial references on opportunistic political business cycles are Fair (1978); Kramer (1971); Lindbeck (1976); Nordhaus (1975) and Tufte (1975) - among others - who focused on cycles in monetary (macro) variables. Subsequent studies have switched attention to political cycles in fiscal variables, being the works Frey \& Schneider (1978a); Frey \& Schneider (1978b); Rogoff (1990); Rogoff \& Sibert (1988) and Tufte (1978) the main initial references.

${ }^{2}$ Key studies on partisan cycles are Alesina (1987); Alesina \& Roubini (1992); Alesina, Roubini \& Cohen (1997); Beck (1982); Hibbs Jr. (1977) and Sheffrin (1989).

${ }^{3} \mathrm{~A}$ seminal and comprehensive analysis of the political determinants - including election cycles - of public spending in Latin America is found in Ames (1987). Barberia \& Avelino (2011) explore how political budget cycles are affected by democratic experience in Latin America. Sakurai \& Menezes Filho (2011) offer a new test of both the opportunistic and partisan budget cycles in Brazilian municipalities.
} 
punishes - rather than rewards - electoral year increases in deficit 4 . Yet, Drazen \& Eslava (2010) explain that voters' fiscal conservatism is perfectly aligned with opportunistic PBCs in certain types of expenditures. They develop a model in which fiscal conservative voters are averse to higher public spending in general, but have an appetite for particular types of targeted spending. As a result, PBCs can take place via a change in the composition of spending, leaving total spending and budget balances unchanged. They confirm their predictions using data on local elections in Colombia ${ }^{5}$.

Following a different perspective, Jones, Meloni \& Tommasi (2012) explain that increases in overall spending are perfectly consistent within a "voters as fiscal liberals" context. They argue that in some federalist systems, such as those in Argentina, Brazil and Russia, the local provision of public services is mostly financed by federal funds - and not by local tax revenues - with the result that rational voters demand more government spending rather than less. Their main argument is that in the context of fiscal federalism, local voters may reap the benefits of public spending without directly paying for its costs. They empirically confirm their proposition by analyzing the case of Argentine fiscal federalism.

The need to account for the effects of fiscal federalism in the analysis of PBCs have been previously addressed by Alt \& Lassen (2006), who have highlighted the important role played by regional and local governments in fiscally decentralized political systems. The authors claim that central governments operating in these systems can affect fiscal outcomes at the local level through the strategic allocation of discretionary transfers. One good example is found in Berry, Burden \& Howell (2010), who examine the distribution of federal outlays in the United States to conclude that districts and counties whose legislative representative belongs to the president's party are systematically rewarded with more federal transfers. Larcinese, Rizzo \& Testa (2006) reach similar findings at the state level, showing that American states with governors belonging to the president's party receive more federal funding. However, neither studies test if these politically motivated transfers increase or not during elections. Yet, other studies have combined the analyses of tactical allocation with political fiscal cycles. Rumi (2008) and Lema \& Streb (2013), for example, show that Argentine provinces politically aligned with the central government receive more voluntary federal transfers in election years. Ferreira \& Bugarin (2007) reach similar conclusions for the Brazilian federal system, showing that mayors who are politically aligned with either the President or State Governors receive more voluntary transfers from these upper government levels during elections.

Recently, studies on political cycles have emphasized that the presence and magnitude of electoral fiscal cycles are conditioned on certain institutions and political and economic contexts (Aidt, Veiga \& Veiga (2010); Brender \& Drazen (2005); Franzese \& Jusko (2008); Rose (2006); Schneider (2010); Shi \& Svensson (2006); Vergne (2009)). A good survey on the conditional political budget cycles literature is found in De Haan \& Klomp (2013a), who discuss the role of various factors influencing political fiscal cycles, such as development levels, democratic experience, political institutions and fiscal rules. Following the well-cited works of Brender \& Drazen (2005) and Shi \& Svensson (2006) for example, for whom the presence and magnitude of fiscal cycles are greatly dependent, respectively, on the democratic experience and on the development levels of countries, many scholars have come to agree that young developing democracies are particularly prone to fiscal opportunism. However, some recent studies have shown that governments in developed and democratic nations also enact opportunistic fiscal cycles depending on their political and institutional conditions. Alt \& Lassen (2006) examine a panel of 19 OECD countries over the nineties to conclude that electoral year deficits are significantly higher in developed countries with lower fiscal transparency and higher political polarization. Streb, Lema \& Torrens (2009) present evidence that PBCs are present in both

\footnotetext{
${ }^{4}$ Arvate, Avelino \& Tavares (2009) analyze state-level elections for governors in Brazil and show that Brazilian voters are in general fiscal conservatives, but after controlling for some measurements of voters' sophistication (such as income, inequality and education), more naive voters punish deficits much less severely.

${ }^{5}$ Schneider (2010) applies the composition of expenditures approach to German states, while Vergne (2009) presents results for a sample of developing countries.
} 
young and established democracies when legislative checks and balances over executive discretion are weak. Other studies focused on subnational governments in developed and democratic countries have shown that strict fiscal rules have important limiting effects on political budget cycles (Rose (2006); Schneider (2010) $)^{6}$.

Term limits are a key institutional rule to be considered in the analysis of conditioned political cycles, but have been somewhat neglected by the literature. Most existing studies on term limits are restricted to legislative mandates 7 . In those in which the chief executive is the central object of analysis, the focus has been on differences in the average fiscal behaviour of term limited and nonterm limited incumbents, with no particular emphasis on the crucial role of elections. This omission is critical, once the prospects of holding office in the future are considered the key driver for the emergence of opportunistic fiscal policies (Rogoff (1990)). In the absence of reelection incentives, fiscal cycles should be mitigated, since a term limited incumbent would have no incentive to signal superior competence levels during elections.

The paper by Besley \& Case (1995) is perhaps the most famous study addressing the effects of executive term limits on fiscal performance. They develop and test a model in which incumbents care more about their reputation if they are eligible to run for a second mandate. Therefore, when two (or more) terms are allowed, incumbents who provide higher first-term payoffs to voters have higher chances of being reelected 8 . Based on data for 48 U.S. states from 1950 to 1986, their results show that governors who cannot stand for reelection tax and spend more during their whole mandate, deviating from the preferences of the median fiscal conservative American voter (Peltzman (1992)).

Still within American states but in a relatively different perspective, List \& Sturm (2006) find evidence that term-limited U.S. governors do not only modify the management of fiscal indicators, but also the implementation of environmental policies. The recent paper by Alt, Mesquita \& Rose (2011) deepens the analysis on the effects of term limits on accountability and competence in U.S. states. By exploiting variations in term limits across space and time both within and between American states and also controlling for tenure in office, they find that under reelection-eligible incumbents, economic activity is higher and taxes and spending lower compared to term-limited incumbents who have equal years of experience in office, which is evidence of an accountability effect. Moreover, when both incumbents are not eligible for reelection, policy outcomes are better under second (last) term incumbents than under first (last) term ones, confirming a competence effect.

Johnson \& Crain (2004) extend the empirical strategy of Besley \& Case (1995) to a panel of democratic countries and find that last term incumbents who cannot run for reelection promote higher increases in expenditures and taxes. They point that these effects are stronger under a single-term limit rule than under a two-terms limit one. However, while a two-terms limit system is associated with lower size of government, it promotes higher fiscal volatility. Nogare \& Ricciuti (2011) reach substantially different findings in their recent cross-country analysis: their results reject any significant effects of term limits on overall spending and budget deficits. The only significant (but negative) effect of term limits is found in social services and welfare expenditures in presidential systems. The authors explain that this finding is consistent with the idea that term-limited incumbents care less about their reputation, since lower provision of social spending might well be contrary to the fiscal

\footnotetext{
${ }^{6}$ In a recent empirical work, De Haan \& Klomp (2013b)analyse 65 democratic countries between 1975 and 2005 to show that the presence of political budget cycles varies significantly, comprising both developing and developed countries, as well as young and old democracies

${ }^{7}$ See, for instance, the recent study by Aidt \& Shvets (2012) and the references therein. By analysing the allocation of pork barrel spending within legislative districts in seven US states, the authors show that term limited legislators reduce the amount of state transfers to their districts when they cannot seek reelection.

${ }^{8}$ Smart \& Sturm (2006) offer a theoretical model in which reputational concerns may be inefficient in the absence of term limits. Their main conclusion is that a two-terms limit system (or more) is preferable to a single or no-term limit system, because in those systems, there is a combination of selection and truthfulness effects, where voters are able to select the best incumbents and these have little incentive to deviate from their true type even in their first terms.
} 
preferences of fiscal liberal voters in such presidential systems.

Out of U.S. states and cross-country comparisons, studies relating term limits and PBCs at the local level are scarce. For example, the works of Rosenberg (1992) in Israel, Meneguin \& Bugarin (2001) and Nakaguma \& Bender (2006) in Brazil or Aidt, Veiga \& Veiga (2010) in Portugal are mainly interested in analyzing the relationships between reelection probabilities, the incumbent's decision to run for reelection and political cycles, but not in addressing the issue of term limits. The difference is that while term limits are an exogenous condition, the decision to run is an endogenous choice of the incumbent.

It is clear from the literature review above that studies concerned with the relationships between term limits and political budget cycles are mainly restricted to the U.S. states and to a few crosscountry analyses. The present paper fills this gap by exploring the effects of term limits on political budget cycles in local governments in Brazil. In this respect, our sample of Brazilian municipalities allows us to hold relevant institutional and economic factors constant, which is always a challenge in cross-country analysis (Schneider (2010)). Moreover, this paper's econometric specification and choice of variables explicitly control for potential sources of tactical allocation between the federal or state governments and municipalities, allowing a precise estimate of the marginal effects of term limits on local fiscal choices. Additionally, this study compliments the most recent conditional political budget cycles literature (De Haan \& Klomp (2013a)) as Brazil, a young developing presidential democracy, has implemented important institutional changes affecting elections and fiscal policies in the past 15 years. Among those, we focus specifically on the Reelection Amendment (Constitutional Amendment n. 16, 1997), which relaxed restrictions on term limits - from one-term to two-terms term limits - allowing executive chiefs to run for reelection for one consecutive term. More precisely, we look at how differences in term limits affect the fiscal behaviors of mayors in Brazil, especially during elections. To our knowledge, this is the first empirical study to address the effects of term limits on fiscal policy at the local level in Latin America ${ }^{9}$.

\section{Institutional context}

Brazil is organized as a republican federation under a presidential system. Its federalist structure comprises three autonomous and independent government levels: the Union, 26 states (plus the federal district, holding the capital Brasília) and 5,565 municipalities. With almost 140 million voters, Brazil is one of the most politically decentralized countries in the world. Upon the ending of military dictatorship in 1984 and with the new Constitution of 1988, elections have been held in a regular basis with fixed dates (usually in October), making the electoral calendar strictly exogenous and perfectly known in advance by both voters and politicians. Having experienced fourteen regular and democratic elections since then, the country can be considered a young developing democracy 10

Until the 1998 national elections, chief executives (President, state governors and city mayors) stood in office for four years only. But with the Reelection Amendment approved in 1997, term limits have been extended to allow for an extra four-year term in office in the case of reelection, permitting eight consecutive years in office. In the case of local governments, the elections held in 2000 were the first in which all incumbent mayors were allowed to run for reelection ${ }^{11}$.

\footnotetext{
${ }^{9}$ Ferraz \& Finan (2011) addressed the effects of term limits on Brazilian mayors' political corruption, but not on fiscal policies. Their results suggest that Brazilian mayors in their first term are less corrupt than those in their second and last term.

${ }^{10}$ Chief executives of the three government levels are chosen by a majority rule, whereas Legislative council members are appointed by a proportional rule. Elections for mayors in cities with more than 200,000 voters follow an absolute majority rule in a two-round system, where the candidate who receives more than $50 \%$ of the valid votes in the first round is elected. If that percentage is not reached, then the two highest-polling candidates meet again in a second and final round. In cities with less than 200,000 voters, a one round system based on a simple majority rule is adopted.

${ }^{11}$ In our sample of 3,393 municipalities, 2,112 incumbent mayors ran for reelection in $2000(62 \%)$, from which 1,227 were reelected $(36 \%)$.
} 
Local politics play an important role in the Brazilian federal system. First, the new democratic constitution of 1988 established that the federal, state and municipal governments are commonly responsible for the provision of a wide variety of policies. However, it also established that most public services should be provided primarily by local administrations, with state and federal governments assuming a subsidiary role. Second, although the fiscal structure in the Brazilian federal system is characterized by high centralization of tax revenues at the federal level, there is high decentralization of expenditures and provision of public services at the local level. For the average municipality, for example, local taxes represent little more than $6 \%$ of its total revenues. But while the average Brazilian municipality is highly dependent on federal and state transfers (both legal and discretionary ones), there is some considerable level of discretion over expenditure allocation. Hence, to the eyes of local citizens, mayors hold the main responsibility for the level and quality of local public services. Finally, municipalities constitute the smaller electoral district in Brazil, being therefore the main geographical unit where votes are cast in local, state and national elections. As a result, much of the political game is played at the municipal level.

In the past 15 years, Brazil has undergone important institutional changes affecting the electoral and fiscal incentives of politicians. Three deserve particular attention: the Reelection Amendment (of greater concern here), the new Electoral Legislation and the Law of Fiscal Responsibility. The Reelection Amendment affected fiscal outcomes by promoting different electoral incentives for incumbents in their first and last terms, as have been discussed by the literature on term limits ${ }^{12}$, This paper contributes to this discussion by exploring the different electoral incentives faced by Brazilian mayors in their first and last term: 13 .

Whereas fiscal opportunism has expectedly increased with the Reelection Amendment, it was probably counterbalanced by the effects of the new Electoral Legislation (Federal Law n. 9504, 1997). According to this law, incumbent politicians are legally impeded, three months before elections, to participate in the inauguration of public works; to implement administrative changes affecting staff, public employees and civil servants (especially promoting new hires and nominations) and to make voluntary transfers to lower government levels (from the Union to states and municipalities, or from states to municipalities). Additionally, six months before elections, incumbent politicians cannot adopt revision of salaries and payments of public employees to a level in excess of the inflation rates prevailing in the ongoing election year. Thus, the Electoral Legislation most probably reduced the scope for fiscal opportunism in some expenditures, especially those related to current spending, such as personnel expenditures for instance.

As for the Law of Fiscal Responsibility (Complementary Law n. 101, 2000), known as one of the most relevant and comprehensive fiscal adjustment plans in Brazilian history, a series of limitations and rules related to the fiscal management of all government levels were created, especially restricting new deficits and debts. For example, it imposed limits on the share of personnel expenditures over net current revenues. It also introduced new rules promoting transparency, control and monitoring of fiscal activity, providing voters greater access to governments' budgets as well as a greater ability to evaluate governments' fiscal performance.

While in this paper we are particularly concerned with the effects of the Reelection Amendment on fiscal policy, our analysis must take into account that Brazilian mayors are restricted by the Electoral Legislation and the Law of Fiscal Responsibility. In this scenario, we propose that the ideal place to look for evidence of political cycles is not in total spending or budget deficits, but mainly and mostly in changes in the composition of the budget (Drazen \& Eslava (2010); Rogoff (1990); Schneider (2010)). From this perspective, politicians may engage into opportunistic fiscal

\footnotetext{
${ }^{12}$ Alt, Mesquita \& Rose (2011); Besley \& Case (1995); Nogare \& Ricciuti (2011); Smart \& Sturm (2006)

${ }^{13}$ Although mayors, state governors and the President are limited to hold office for only two consecutive terms, they can run again for the same post after a one-term hiatus (four years), which should make them more concerned about future reputation and thus more accountable today. In the case of mayors, however, Ferraz \& Finan (2011) explain that the low probability of returning to political office again makes the average second-term mayor to behave as a lame duck.
} 
policies by moving from less visible to more visible and electorally effective types of spending, without increasing total expenditures or promoting deficits. Regardless of whether Brazilian voters are fiscal conservatives (Peltzman (1992)) or fiscal liberals (Jones, Meloni \& Tommasi (2012)), we believe that the current institutional setting in Brazil has resulted in politicians having "one hand tied behind their backs", where the change in the composition of the budget becomes a second best strategy (Schneider (2010)).

\section{Data description}

The data set used in this study contains electoral, fiscal and economic variables for a sample consisting of an eight years (2001-2008) balanced panel of 3,393 Brazilian municipalities, which represents $61 \%$ of the 5,565 municipalitie: ${ }^{14}$. Electoral data were obtained from the Superior Electoral Tribunal, while municipal fiscal data were taken from the Secretary of National Treasury. The source of demographic and economic data, in turn, is the Brazilian Institute of Geography and Statistics. All fiscal variables are in real per capita terms, in Brazilian currency units (Real-R $\$$ ) at 2008 prices (adjusted by using the IPCA). It is important to clarify that the time frame under analysis includes two local mandates, namely, 2001 - 2004 (mayors elected in October of 2000) and 2005 - 2008 (mayors elected in October of 2004), so that in each of them, there are both mayors who can and cannot run for a subsequent mandate 15

Various budget categories for the fiscal dependent variables are analyzed in this study, namely: (i) Budget Balance; (ii) Total Spending; (iii) Local Tax Revenues; (iv) Current Expenditures; (v) Personnel Expenditures and finally (vi) Capital Investments. These fiscal variables were chosen based on both their traditional presence over the PBC literature and on their relevance for testing opportunistic fiscal cycles at the municipal level in Brazil. According to the classical PBC hypothesis, one should expect a decrease in revenues (especially tax revenues) and an increase in spending during elections, leading to a decrease in the fiscal balance. Following the most recent literature, focused on the change in the composition of spending under a fiscal conservative context (e.g. Schneider (2010); Drazen \& Eslava (2010)), one should expect increases in those types of expenditures which voters care more about and decreases in those that are found to be less attractive to the electorate, so that the overall balance should remain unchanged.

Table 1 is a good starting point to begin our analysis of the effects of term limits on political budget cycles at the municipal level in Brazil. The last column from the table indicate that the percentage share of tax revenues, current expenditures and personnel expenditures (over total revenues) are reduced during elections to a greater extent under first term mayors than under last term mayors. First term mayors also present a relatively greater increase in the share of capital investments during elections compared to last term mayors. This change in the composition of the budget (reductions in current expenditures and increases in capital investments) comes with an improvement in the budget balance, as capital expenditures represent a much smaller fraction of total spending than current expenditures. Thus, a small reduction in the share of current expenditures followed by a similar percentage increase in the share of capital investments allows for an improvement in the budget balance.

\footnotetext{
${ }^{14}$ Due to data unavailability for important variables, the remaining 2,172 municipalities had to be excluded from the sample. This exclusion could theoretically generate a sample bias if quality and consistency of fiscal reporting is an attribute of the "best" local administrations. In this sense, the true effects of fiscal opportunism might be different than those found here. For instance, the excluded municipalities might present worse fiscal conditions than those in the present sample.

${ }^{15}$ The descriptive statistics are presented in Table A.1, in the appendix.
} 
Table 1: Mean differences in fiscal variables for first and second term mayors - percentage share over total revenues

\begin{tabular}{|c|c|c|c|c|c|c|c|}
\hline \multirow{3}{*}{$\begin{array}{c}\text { Fiscal } \\
\text { Variable } \\
\text { (\% share over } \\
\text { total revenues })\end{array}$} & \multicolumn{4}{|c|}{ First Term Mayor } & \multicolumn{2}{|c|}{ Last Term Mayor } & \multirow[t]{2}{*}{ First x Last Term Mayors } \\
\hline & $\begin{array}{c}\text { Electoral } \\
\text { Year }\end{array}$ & $\begin{array}{l}\text { Non Electoral } \\
\text { Years }\end{array}$ & $\begin{array}{l}\text { Electoral } \\
\text { Year change }\end{array}$ & $\begin{array}{l}\text { Electoral } \\
\text { e Year }\end{array}$ & $\begin{array}{l}\text { Non Electoral } \\
\text { Years }\end{array}$ & $\begin{array}{l}\text { Electoral } \\
\text { Year change }\end{array}$ & \\
\hline & (A) & (B) & $(\mathrm{A})-(\mathrm{B})$ & (E) & $(\mathrm{F})$ & $(\mathrm{E})-(\mathrm{F})$ & $(\mathrm{A}-\mathrm{B})-(\mathrm{E}-\mathrm{F})$ \\
\hline $\begin{array}{c}\text { Total } \\
\text { Expenditures }\end{array}$ & $96,83 \%$ & $97,99 \%$ & $-1,16 \% * * *$ & $98,04 \%$ & $98,49 \%$ & $-0,45 \% * * *$ & $-0,71 \% * * *$ \\
\hline $\begin{array}{l}\text { Budget } \\
\text { Balance }\end{array}$ & $3,17 \%$ & $2,01 \%$ & $1,16 \% * * *$ & $1,96 \%$ & $1,50 \%$ & $0,46 \% * * *$ & $0,70 \% * * *$ \\
\hline $\begin{array}{c}\text { Tax } \\
\text { Revenues }\end{array}$ & $6,60 \%$ & $6,73 \%$ & $-0,14 \%^{N S}$ & $6,70 \%$ & $6,63 \%$ & $0,07 \%^{N S}$ & $-0,21 \% * * *$ \\
\hline $\begin{array}{c}\text { Current } \\
\text { Expenditures }\end{array}$ & $83,74 \%$ & $86,00 \%$ & $-2,26 \% * * *$ & $84,13 \%$ & $84,70 \%$ & $-0,57 \% * * *$ & $-1,70 \% * * *$ \\
\hline $\begin{array}{c}\text { Personnel } \\
\text { Expenditures }\end{array}$ & $42,57 \%$ & $43,44 \%$ & $-0,86 \% * * *$ & $42,18 \%$ & $41,98 \%$ & $0,19 \%^{N S}$ & $-1,06 \% * * *$ \\
\hline $\begin{array}{c}\text { Capital } \\
\text { Investments }\end{array}$ & $11,25 \%$ & $10,06 \%$ & $1,19 \% * * *$ & $12,12 \%$ & $11,92 \%$ & $0,20 \%^{N S}$ & $1,00 \% * * *$ \\
\hline Municipalities & & 2.386 & & & 1.007 & & 3.393 \\
\hline
\end{tabular}

Source: authors' calculations

Notes: Municipalities refer to the average number of municipalities with first term and last term mayors for the whole period (2001-2008). The sample comprises a balanced panel of 3,393 municipalities.

Asterisks refer to statistically significant differences at $*=10 \% ; * *=5 \%$ and ${ }^{* * *}=1 \%$, respectively. NS refers to differences not statistically significant.

\section{$5 \quad$ Empirical methodology}

This study builds on the work of Besley \& Case (1995) by testing not only the effects of term limits on the fiscal choices of incumbents for their whole mandate, but in particular, their specific behaviour in election years. We test for the presence and magnitude of opportunistic fiscal cycles in Brazil using the following linear dynamic panel model:

$F V_{i t}=\alpha+f_{i}+\gamma \cdot F V_{i t-1}+\beta_{1} \cdot E L E C_{t}+\beta_{2} \cdot T E R M_{i t}+\beta_{3} \cdot\left(E L E C_{t} \cdot T E R M_{i t}\right)+$ Control Variables $+\epsilon_{i t}$

where the dependent variable $F V_{i t}$ is the natural $\log$ of a fiscal variable observed for municipality $i$ in year $t$ (excluding the budget balance, measured in absolute terms as it can assume negative values), $\alpha, f_{i}$ and $\epsilon_{i t}$ are, respectively, the constant term, the municipal fixed effects and the idiosyncratic error. The variable $E L E C_{t}$ is a time dummy equal to 1 in the electoral year and 0 otherwise, while $T E R M_{i t}$ is an individual dummy equal to 1 for a first term mayor and 0 for a second term mayor. The interaction $E L E C_{t} * T E R M_{i t}$ is the main variable of interest in this study, which is equal to 1 for a first term mayor in an election year and 0 otherwise. Thus, $\beta_{3}$ identifies the additional positive fiscal stimulus in an election year resulting from the possibility of reelection.

According to the main PBC hypotheses, it is expected that $\beta_{3}>0$ for expenditure variables (on average, first term mayors increase public spending during electoral years more than second term mayors) and $\beta_{3}<0$ for revenues variables (on average, first term mayors reduce taxation and collection during electoral years more than second term mayors). Given this pattern of higher spending and lower revenue collections, it is expected that $\beta_{3}<0$ for the overall budget balance.

The set of control variables accounts for other political and demographic determinants of fiscal policy, namely: (i) the lag of constitutional transfers received by municipalities from both state and federal governments, accounting for legally determined resources available to local governments; (ii) the index of votes fractionalization in the last election, given by the formula $1-\sum_{j=1}^{J} v_{j}^{2}$, in which $v_{j}$ is the share of votes obtained by each candidate $j$ running for mayor at municipality $i$ - the higher the 
index, the more fragmented are voters' preferences, making it harder for the mayor to define what set or mix of fiscal policies are more electorally effective; (iii) a dummy indicating the political alignment between the mayor's and the governor's parties and (iv) a dummy indicating the political alignment between the mayor's and the president's parties - following similar arguments as those presented by Ferreira \& Bugarin (2007), Lema \& Streb (2013) and Rumi (2008), it could be that mayors whose parties belong to the governor's and/or President's parties receive more voluntary transfers and grants from the state and/or federal governments, especially during electoral periods; and (v) two political dummies - right and left - indicating the ideological orientation of the mayor's party, in order to account for potential partisan effects on fiscal policy ${ }^{16}$. As demographic controls, we included (vi) total population, (vii) proportion of elderly (people over 65 years old) and (viii) young (people below 14 years old) living in each municipality. The inclusion of population size is used to account for the demand for government services and also for the degree of political accountability, which is thought to be inversely proportional to the size of the electoral district (Porto \& Porto (2000)). The age structure of the population (proportion of elderly and young) has become a standard approach in the PBC literature for capturing variations in the demand for government services (Brender \& Drazen (2005); Rose (2006); Sakurai \& Menezes Filho (2011); Veiga \& Veiga (2007)).

Given that fiscal variables usually exhibit persistence over time, the estimations include the first lag of the dependent variable as an additional regressor. However, as is well known, the inclusion of a lagged dependent variable and of municipal fixed effects lead to inconsistent OLS estimators. First differencing Equation 1 eliminates the fixed effects, but results in $\Delta F V_{i t-1}$ being correlated with $\Delta \epsilon_{i t}$. To solve this endogeneity problem, estimations were performed according to the System-GMM (General Method of Moments) procedure proposed by Blundell \& Bond (1998), which uses lags of the dependent variable, in levels, as instruments for the differenced equation, and one lag of the dependent variable, in differences, as instruments for the level equation. Additionally, the standard errors were clustered at the municipal level and adjusted for finite sample sizes using the Windmeijer (2005) correction.

\section{Results}

In this section, we present the results generated from the estimation of Equation 1 for the six selected fiscal variables using the Blundell \& Bond (1998) system-GMM method. The list of instruments, Sargan tests of instrument validity and the $m_{1}$ and $m_{2}$ tests of absence of first and second-order correlated errors terms are reported at the bottom of the tables. The Windmeijer (2005) robust standard errors (corrected for finite samples) are reported in parentheses.

The main variable of interest is the interaction $E L E C_{t} * T E R M_{i t}$ (Electoral Year x First Term Mayor), which identifies the difference in the examined fiscal variable between first term and second term mayors over the electoral and non-electoral periods $\left(\beta_{3}\right)$. Two other important variables capturing the effects of elections and term limits on fiscal policy are $E L E C_{t}$ (Electoral Year) and $T E R M_{i t}$ (First Term Mayor). The results regarding $E L E C_{t}$ correspond to the electoral year difference in fiscal variable for second term mayors $\left(\beta_{1}\right)$, while the results for $T E R M_{i t}$ identifies the difference in the term's average fiscal variable (non-electoral years) between first term and second term mayors $\left(\beta_{2}\right)$.

Before reviewing the results displayed in Table 2, note that all the estimations comply with the Sargan test, i.e. the selected set of instruments exhibits no correlation with the error term. Additionally, the $m_{2}$ test indicates that the differenced error term exhibits no second-order correlation. Also, the first lag of the dependent variable is significant only in the case of overall budget balance (positive) and capital investments (negative), suggesting that throughout the period under analysis,

\footnotetext{
${ }^{16}$ We classified the political parties in the sample as left, right and center (the base-group) based on Mizuca (2007) and Rodrigues (2002).
} 
budget balances have improved and investments have deteriorated.

The figures in Table 2 confirm the presence of political cycles in local tax revenues, current expenditures and capital investments at the local level in Brazil, but not in the budget balance, total expenditures or personnel expenditures. While mayors in their second (and final) term increase taxes and current expenditures during elections (see the positive coefficients for Electoral Year), first term mayors do exactly the opposite (see the negative coefficients for the interaction Electoral Year $\mathrm{x}$ First Term). A similar but inverse pattern occurs for capital investments: while last term mayors reduce investments in election years, first term mayors substantially increase them. Fiscal differences over the term in office (non-electoral years) are practically negligible (see the statistically insignificant coefficients for First Term Mayor), with the exception being smaller levels of total expenditures under first term mayors. These figures show that first term mayors behave opportunistically by promoting reductions in local taxation and in current expenditures and increases in capital investments. Moreover, they do so without affecting the budget balance, overall spending or personnel expenditures.

Table 2: First term x Second term mayors - System-GMM estimations

\begin{tabular}{|c|c|c|c|c|c|c|}
\hline $\begin{array}{c}\text { Coefficient } \\
\text { (Standard deviation) }\end{array}$ & $\begin{array}{l}\text { Budget } \\
\text { Balance }\end{array}$ & $\begin{array}{c}\text { Tax } \\
\text { Revenues }\end{array}$ & $\begin{array}{c}\text { Total } \\
\text { Expenditures }\end{array}$ & $\begin{array}{c}\text { Current } \\
\text { Expenditures }\end{array}$ & $\begin{array}{c}\text { Personnel } \\
\text { Expenditures }\end{array}$ & $\begin{array}{c}\text { Capital } \\
\text { Investments }\end{array}$ \\
\hline Electoral year & $\begin{array}{c}23.782 \\
(43.299)\end{array}$ & $\begin{array}{l}0.513^{*} \\
(0.296)\end{array}$ & $\begin{array}{c}0.043 \\
(0.078)\end{array}$ & $\begin{array}{c}0.288^{* * *} \\
(0.086)\end{array}$ & $\begin{array}{c}0.130 \\
(0.188)\end{array}$ & $\begin{array}{c}-5.844^{* * *} \\
(1.876)\end{array}$ \\
\hline First term mayor & $\begin{array}{c}-81.913 \\
(162.818)\end{array}$ & $\begin{array}{c}0.362 \\
(2.618)\end{array}$ & $\begin{array}{c}-0.625^{* *} \\
(0.292)\end{array}$ & $\begin{array}{l}-1.333 \\
(1.114)\end{array}$ & $\begin{array}{l}-0.007 \\
(0.609)\end{array}$ & $\begin{array}{l}-0.868 \\
(2.210)\end{array}$ \\
\hline Electoral year x First term mayor & $\begin{array}{l}-47.590 \\
(67.125)\end{array}$ & $\begin{array}{l}-0.669^{*} \\
(0.366)\end{array}$ & $\begin{array}{l}-0.036 \\
(0.107)\end{array}$ & $\begin{array}{c}-0.312^{* *} \\
(0.124)\end{array}$ & $\begin{array}{l}-0.132 \\
(0.276)\end{array}$ & $\begin{array}{l}7.953^{* * *} \\
(2.638)\end{array}$ \\
\hline Constitutional transfers (lag) & $\begin{array}{l}-235.187 \\
(192.097)\end{array}$ & $\begin{array}{c}1.411^{* * *} \\
(0.512)\end{array}$ & $\begin{array}{c}0.705^{* * *} \\
(0.179)\end{array}$ & $\begin{array}{c}1.601^{* * *} \\
(0.315)\end{array}$ & $\begin{array}{c}1.074^{* * *} \\
(0.126)\end{array}$ & $\begin{array}{c}2.474 \\
(1.585)\end{array}$ \\
\hline Right & $\begin{array}{l}-239.047 \\
(467.855)\end{array}$ & $\begin{array}{c}2.996 \\
(6.857)\end{array}$ & $\begin{array}{l}-0.182 \\
(0.604)\end{array}$ & $\begin{array}{l}-1.199 \\
(2.013)\end{array}$ & $\begin{array}{l}-0.058 \\
(2.201)\end{array}$ & $\begin{array}{l}-5.618 \\
(9.087)\end{array}$ \\
\hline Left & $\begin{array}{c}292.258 \\
(626.409)\end{array}$ & $\begin{array}{c}2.581 \\
(2.780)\end{array}$ & $\begin{array}{c}0.372 \\
(0.361)\end{array}$ & $\begin{array}{c}2.835 * * \\
(1.399)\end{array}$ & $\begin{array}{c}0.158 \\
(1.526)\end{array}$ & $\begin{array}{l}-0.725 \\
(5.857)\end{array}$ \\
\hline Fractionalization of votes & $\begin{array}{l}-1047.208 \\
(1104.522)\end{array}$ & $\begin{array}{c}8.175 \\
(9.982)\end{array}$ & $\begin{array}{c}2.778 \\
(1.891)\end{array}$ & $\begin{array}{c}4.522 \\
(5.802)\end{array}$ & $\begin{array}{c}9.182 \\
(7.244)\end{array}$ & $\begin{array}{l}-22.711 \\
(32.664)\end{array}$ \\
\hline Alignment with State government & $\begin{array}{l}-342.510^{*} \\
(179.948)\end{array}$ & $\begin{array}{c}-0.899^{*} \\
(0.489)\end{array}$ & $\begin{array}{c}0.454 \\
(0.320)\end{array}$ & $\begin{array}{c}-1.040^{* * *} \\
(0.356)\end{array}$ & $\begin{array}{c}-0.885^{* * *} \\
(0.220)\end{array}$ & $\begin{array}{l}-9.850 \\
(8.099)\end{array}$ \\
\hline Alignment with Federal government & $\begin{array}{l}413.678^{*} \\
(220.252)\end{array}$ & $\begin{array}{c}-1.651^{* *} \\
(0.722)\end{array}$ & $\begin{array}{c}0.032 \\
(0.199)\end{array}$ & $\begin{array}{c}-1.076 * * * \\
(0.183)\end{array}$ & $\begin{array}{c}-0.809 * * * \\
(0.230)\end{array}$ & $\begin{array}{l}-4.775 \\
(5.623)\end{array}$ \\
\hline Total population & $\begin{array}{c}69.461 \\
(110.289)\end{array}$ & $\begin{array}{c}0.463 \\
(0.338)\end{array}$ & $\begin{array}{l}-0.105 \\
(0.103)\end{array}$ & $\begin{array}{l}-0.622 \\
(0.496)\end{array}$ & $\begin{array}{l}-0.322 \\
(0.538)\end{array}$ & $\begin{array}{c}0.378 \\
(0.788)\end{array}$ \\
\hline Elderly & $\begin{array}{l}10760.413 \\
(7363.090)\end{array}$ & $\begin{array}{c}4.871 \\
(35.478)\end{array}$ & $\begin{array}{c}19.405 \\
(15.873)\end{array}$ & $\begin{array}{c}13.813 \\
(23.880)\end{array}$ & $\begin{array}{c}0.081 \\
(10.542)\end{array}$ & $\begin{array}{l}-11.180 \\
(76.155)\end{array}$ \\
\hline Young & $\begin{array}{c}542.551 \\
(1857.210)\end{array}$ & $\begin{array}{l}12.746^{*} \\
(6.778)\end{array}$ & $\begin{array}{c}1.612 \\
(3.465)\end{array}$ & $\begin{array}{c}4.013 \\
(4.363)\end{array}$ & $\begin{array}{l}-2.850 \\
(3.956)\end{array}$ & $\begin{array}{c}1.124 \\
(20.292)\end{array}$ \\
\hline First lag of dependent variable & $\begin{array}{c}0.102^{* *} \\
(0.044)\end{array}$ & $\begin{array}{c}0.092 \\
(0.078)\end{array}$ & $\begin{array}{c}0.157 \\
(0.248)\end{array}$ & $\begin{array}{l}-1.091 \\
(0.740)\end{array}$ & $\begin{array}{l}-0.523 \\
(0.487)\end{array}$ & $\begin{array}{c}-2.014^{* *} \\
(0.922)\end{array}$ \\
\hline Constant & $\begin{array}{c}649.616 \\
(2216.157)\end{array}$ & $\begin{array}{l}-20.105^{*} \\
(11.596)\end{array}$ & $\begin{array}{l}-0.875 \\
(1.770)\end{array}$ & $\begin{array}{c}6.049 \\
(6.304)\end{array}$ & $\begin{array}{c}1.535 \\
(6.876)\end{array}$ & $\begin{array}{l}11.718 \\
(9.815)\end{array}$ \\
\hline Observations $(\mathrm{NxT})$ & 27,144 & 27,144 & 27,144 & 27,144 & 27,144 & 27,144 \\
\hline $\begin{array}{l}\text { Instruments for differenced equation } \\
\text { Instruments for level equation }\end{array}$ & $\begin{array}{l}\text { from } y_{i t-2} \text { to } y_{i t-4} \\
\qquad \Delta y_{i t-1}\end{array}$ & $\begin{array}{c}y_{i t-2} \\
\Delta y_{i t-5}\end{array}$ & $\begin{array}{c}y_{i t-2} \\
\Delta y_{i t-3}\end{array}$ & $\begin{array}{c}y_{i t-2} \\
\Delta y_{i t-3}\end{array}$ & $\begin{array}{c}y_{i t-2} \\
\Delta y_{i t-3}\end{array}$ & $\begin{array}{c}y_{i t-3} \\
\Delta y_{i t-4}\end{array}$ \\
\hline Sargan (p-value) & 0.118 & 0.476 & 0.125 & 0.996 & 0.977 & 0.266 \\
\hline$m_{1}(\mathrm{p}$-value $)$ & 0.000 & 0.582 & 0.010 & 0.052 & 0.763 & 0.037 \\
\hline$m_{2}(\mathrm{p}$-value $)$ & 0.247 & 0.691 & 0.230 & 0.391 & 0.310 & 0.131 \\
\hline
\end{tabular}

Notes: *** Significant at 1\%; ** Significant at 5\%; * Significant at 10\%; Windmeijer (2005) Robust standard errors in parenthesis; Sargan is a test for valid instruments under the null hypothesis, asymptotically distributed as $\chi^{2}$, with degrees of freedom equal to the number of over-identifying restrictions. $m_{1}$ and $m_{2}$ are tests for first and second-order serial correlation in the first-differenced residuals, asymptotically distributed as $\mathrm{N}(0,1)$ under the null hypothesis of no serial correlation. 
The above results suggest that term limits are an important source of variation in fiscal policies during electoral years. First term mayors, facing the reelection incentives presented by another term in office and having the objective of maximizing their reelection probability subject to electoral and fiscal constraints, seem to adopt the so-called "change in the budget composition approach" (Drazen \& Eslava (2010)). By changing the allocation of budgetary resources in electoral periods, first term mayors increase the types of expenditures which are more visible and presumably more appealing to voters (i.e. investments) while keeping a controlled fiscal balance.

These findings are somewhat contrary to the predictions presented by Rogoff (1990). According to Rogoff's model, there should be an increase in government consumption spending during elections and a decrease in capital expenditures. The proposed explanation is that while government consumption spending is contemporaneously observed by voters and offer direct benefits (such as transfers and subsidies), capital expenditures are observed only with a time lag. As examples of capital expenditures, Rogoff (1990) cites investments in national defense (which could be hidden from the eyes of the public due to security reasons), vesting of public pensions, off-budget loan guarantees and other types of capital expenditures whose effects are only observed in the future. The assumptions by Rogoff (1990), however, do not really apply to Brazilian municipalities. For example, expenditures related to national defense, debt service, subsidies to specific sectors and loans are mostly concentrated in the federal government, thus not so relevant for an understanding of political cycles at the municipal level. As for increases in wages and salaries of civil servants and government employees, they are strongly restricted by the Electoral Legislation and Law of Fiscal Responsibility and are thus difficult to manipulate. Besides, since most local current expenditures are channelled to cover bureaucratic and administrative needs (such as personnel expenditures, expenditures on utilities and other purchases of goods and services), it is not obvious that they are readily visible to citizens or have any positive and direct impact on voters' welfare. The opposite is true for capital investments: comprising the acquisition of new equipment, machinery and other capital goods (such as new ambulances, school buses and medical equipment), as well as investments on infrastructure projects (construction of roads, schools, hospitals, social houses, etc), these are highly and timely visible expenditure items (remember that elections take place at the end of the year), besides being undoubtedly welfare improving. All in all, first term mayors in Brazil with an interest in holding office for four more years have strong incentives to increase capital expenditures and decrease current expenditures during elections in order to win the support of voters.

Turning to the effects of the control variables, we see that lagged values of constitutional transfers have a positive and significant effect on both tax revenues and expenditures (no significant effects on budget balance and capital investments), while the effects of political alignment with either the president or governor on these same variables are negative.

Constitutional transfers refer to legally determined redistributions and compensations from the states and the Union to municipalities, based on the shares and quotas the municipalities have over state and federal tax revenues and on their legal share over natural resource revenues (water, minerals and oil). Hence, different municipal characteristics are reflected in varying levels of legal transfers among cities. The results in Table 2 suggest that these legal transfers are associated with an improvement in local tax collection and in overall current expenditures.

As for the negative effects observed for the political alignment between mayors and governors or president, we interpret them as reflecting the various mechanisms through which local public services are provided directly by the state or federal governments when these are politically aligned with local administrations. There are many ways in which this is possible: technical cooperation, financial assistance, in-kind transfers, grants, services provided by decentralized state and federal agencies at the regional and local levels, and through parliamentary amendments to the state and federal budgets. In the latter case, state and federal deputies belonging to the government coalition may allocate direct resources to politically connected mayors. Note that the effects of federal alignment are somewhat greater than those of state alignment. This result may reflect the practice of fiscal federalism in 
Brazil, where the vast majority of municipalities are highly dependent on federal assistance. Finally, it is worth mentioning that while mayors' political alignment with the state government is associated with decreases in budget balances, these are improved when mayors are politically aligned with the federal government. A possible explanation is that the high degree of dependence on federal assistance (especially in the form of voluntary transfers, such as current and capital transfers grants) on the part of most municipalities obligates them to comply with some of the stringent fiscal rules imposed by the federal government ${ }^{17}$.

In order to pursue a deeper analysis of the different incentives faced by first and second term mayors, we decided to investigate whether or not the results change when we compare first term mayors who actively exercise their option to run for reelection to second term mayors. This is an important distinction, given that not all first term mayors do in fact run for reelection - in our data sample, in 2004 elections, among 2,166 first term mayors (i.e.mayors able to be reappointed), only 1,352 ran for a subsequent period of government. In 2008, these values were equal to 2,605 and 1,860, respectively. Therefore, our previous results on the effects of term limits on political cycles, based on the comparison of first term mayors and second term mayors, are probably underestimating the reelection incentives of term limits. Since we expect reelection runners to enact even higher levels of fiscal opportunism, we test this possibility further below.

As the decision made by eligible candidates to run for reelection is clearly endogenous, (i.e. it is the politician's choice, influenced by a set of determinants), we performed estimations in line with the traditional method proposed by Heckman (1979). At first, we undertook a fixed effects (or conditional) logit regression estimating the probability of an eligible candidate running for a subsequent mandate, including the following set of controls: political variables: (i) dummies for political alignment with State and Federal executive government levels, separately for the first and last two years of the local mandate $e^{18}$ - these variables were included in order to capture the potential effect of political support coming from higher levels of government at the executive branch;(ii) share of votes obtained by the mayor's party in the elections for state and federal deputies, which indicates the potential degree of legislative support the mayor enjoys from higher government levels. The higher are these vote shares, the greater may be the allocation of budgetary amendments proposed by the deputies to the municipality; (iii) fractionalization index of votes in the previous local election, in order to control for the heterogeneity of voter's preferences; fiscal variables: (iv) the amount of discretionary grants (current and capital) received from superior (State and Central) levels of government during the whole local mandate (both in natural logarithm), so as to capture the prospects of resources availability coming from upper government levels which can be subject to tactical allocation; demographic variables: municipality's (v) total population (in logs); (vi) proportion of elderly and (vii) young population; mayors' personal characteristics: (viii) age of the mayor (and its square value, in order to capture any non-linear effect), (ix) a dummy for gender (equal to 1 if the mayor is male); (x) a dummy for public servant and finally, (xi) a dummy indicating whether the candidate holds a university degree.

Results generated by the fixed effects logit model are presented in Table 3. Starting with the political variables, mayors are more likely to run for reelection when their party also holds office in both Federal and State governments during the second half of the mandate. On the other hand, this likelihood appears to be lower when the alignment with State and Central government occurs during the first half of a mayor's mandate. Higher share of votes for state and federal deputies appear to reduce the mayors' probability of running for office again, although only the latter is statistically significant. This negative correlation runs counter to our initial predictions. However, we interpret

\footnotetext{
${ }^{17}$ In its articles 23 and 51, for example, the Law of Fiscal Responsibility states that subnational governments may no longer receive voluntary transfers or sign credit operations if they do not comply with the cap limits on personnel expenditures (article 23) or do not report their accounting summaries within the pre-scheduled dates (article 51).

${ }^{18}$ Local elections in Brazil are staggered with State and Federal elections, so that the political alignment between local and higher levels of government can vary within a given local mandate.
} 
this result in a similar fashion as in Castro \& Martins (2013): a party's increased political status at higher government levels increases the mayor's political career options at the end of his term. As we already mentioned, many first term incumbents give up running for reelection as mayors. It could be that some of them opt for a legislative career. In any case, we would need more information to investigate this further. Finally, a higher fractionalization of votes in the previous election increases the probability that a mayor runs for reelection. The reason is that higher fractionalization of votes indicates a wider distribution of votes among competing parties, meaning that electoral contests in these cases are more openly fought.

As for discretionary transfers received by mayors throughout their mandates, only the amount of current grants seems to have a positive and statistically significant (at 10\%) effect on the decision to run for reelection - the coefficient regarding capital transfers grants is not statistically different from zero.

Table 3: Probability of running for reelection - fixed effects (conditional) logit estimation

\begin{tabular}{cc}
\hline Alignment with State government - first half & $-0.232^{* *}$ \\
& $(0.103)$ \\
Alignment with State government - second half & $0.174^{*}$ \\
& $(0.103)$ \\
Alignment with Federal government - first half & -0.174 \\
& $(0.108)$ \\
Alignment with Federal government - second half & $0.719^{* * *}$ \\
& $(0.206)$ \\
Share of votes - State deputy & -0.662 \\
& $(0.971)$ \\
Share of votes - Federal deputy & $-1.704^{* *}$ \\
& $(0.784)$ \\
Fractionalization of votes & $1.342^{* * *}$ \\
& $(0.318)$ \\
& $0.028^{*}$ \\
Current transfers grants (natural logarithm) & $(0.016)$ \\
& 0.014 \\
Capital transfers grants (natural logarithm) & $(0.011)$ \\
& -0.173 \\
Total Population (natural logarithm) & $(0.513)$ \\
& -6.737 \\
Elderly & $(9.478)$ \\
Young & 10.414 \\
Age & $(7.164)$ \\
Age squared & $-0.221^{* * *}$ \\
Male & $(0.036)$ \\
Pubservations (N x T) & $0.002^{* * *}$ \\
& $(0.000)$ \\
& $-0.361^{* *}$ \\
& $(0.175)$ \\
& $-0.727^{* * *}$ \\
& $(0.093)$ \\
& -0.009 \\
& $(0.091)$ \\
4,688 \\
\hline
\end{tabular}

Source: Own authors

Notes: Dependent variable assumes 1 if the local mayor runs for reelection and 0 otherwise.

***Significant at 1\%;** Significant at 5\%; * Significant at 10\%; Standard errors in parenthesis; Time dummies included.

Finally, concerning mayors' personal characteristics, our estimations suggest that age decreases (at a decreasing rate) the likelihood of a mayor choosing to run for reelection. A negative effect is also observed for male and public servant, suggesting that male mayors who have a previous position in the public sector are less likely to run for another term than females or mayors with no history in public service.

As an additional step to solve the endogeneity present in a mayor's decision to run for reelection, we included the Inverse Mills Ratio (calculated according to the logit estimation ${ }^{19}$ ) as a regressor in

\footnotetext{
${ }^{19}$ Given that second term mayors cannot run for reelection, we replaced the estimated linear probability by zero
} 
Table 4: Reelection runners x Second term mayors controlling for selectivity bias - system GMM estimations

\begin{tabular}{|c|c|c|c|c|c|c|}
\hline $\begin{array}{c}\text { Coefficient } \\
\text { (Standard deviation) }\end{array}$ & $\begin{array}{l}\text { Budget } \\
\text { Balance }\end{array}$ & $\begin{array}{c}\text { Tax } \\
\text { Revenues }\end{array}$ & $\begin{array}{c}\text { Total } \\
\text { Expenditures }\end{array}$ & $\begin{array}{c}\text { Current } \\
\text { Expenditures }\end{array}$ & $\begin{array}{c}\text { Personnel } \\
\text { Expenditures }\end{array}$ & $\begin{array}{c}\text { Capital } \\
\text { Investments }\end{array}$ \\
\hline Electoral year & $\begin{array}{c}37.505 \\
(26.324)\end{array}$ & $\begin{array}{c}0.314^{* *} \\
(0.126)\end{array}$ & $\begin{array}{c}0.045 \\
(0.143)\end{array}$ & $\begin{array}{c}0.249 * * * \\
(0.037)\end{array}$ & $\begin{array}{c}0.197 \\
(0.153)\end{array}$ & $\begin{array}{c}-4.344^{* * *} \\
(1.651)\end{array}$ \\
\hline First term mayor (reelection runners) & $\begin{array}{c}914.499 \\
(1158.585)\end{array}$ & $\begin{array}{c}6.188 \\
(9.448)\end{array}$ & $\begin{array}{l}3.289^{*} \\
(1.775)\end{array}$ & $\begin{array}{c}0.215 \\
(2.604)\end{array}$ & $\begin{array}{c}3.551 \\
(3.156)\end{array}$ & $\begin{array}{c}18.450 \\
(34.699)\end{array}$ \\
\hline Electoral year x First term runners & $\begin{array}{l}-68.542 \\
(50.716)\end{array}$ & $\begin{array}{c}-0.472^{* * *} \\
(0.139)\end{array}$ & $\begin{array}{l}-0.038 \\
(0.208)\end{array}$ & $\begin{array}{c}-0.298 * * * \\
(0.059)\end{array}$ & $\begin{array}{l}-0.277 \\
(0.272)\end{array}$ & $\begin{array}{l}6.322^{* *} \\
(2.482)\end{array}$ \\
\hline Constitutional transfers (lag) & $\begin{array}{c}-154.626^{*} \\
(93.605)\end{array}$ & $\begin{array}{c}1.256^{* * *} \\
(0.432)\end{array}$ & $\begin{array}{l}0.876^{* * *} \\
(0.260)\end{array}$ & $\begin{array}{c}1.379^{* * *} \\
(0.213)\end{array}$ & $\begin{array}{c}0.880^{* * *} \\
(0.172)\end{array}$ & $\begin{array}{c}1.472 \\
(1.517)\end{array}$ \\
\hline Right & $\begin{array}{l}-230.568 \\
(248.984)\end{array}$ & $\begin{array}{c}1.281 \\
(3.433)\end{array}$ & $\begin{array}{l}-0.957 \\
(0.784)\end{array}$ & $\begin{array}{l}-1.058 \\
(0.835)\end{array}$ & $\begin{array}{l}-0.702 \\
(1.752)\end{array}$ & $\begin{array}{c}8.194 \\
(21.701)\end{array}$ \\
\hline Left & $\begin{array}{l}-207.531 \\
(428.490)\end{array}$ & $\begin{array}{l}-2.826 \\
(5.958)\end{array}$ & $\begin{array}{l}-2.362^{*} \\
(1.274)\end{array}$ & $\begin{array}{c}1.456 \\
(1.596)\end{array}$ & $\begin{array}{l}-1.562 \\
(1.768)\end{array}$ & $\begin{array}{c}-5.821 \\
(14.643)\end{array}$ \\
\hline Fractionalization of votes & $\begin{array}{l}-2520.285 \\
(1738.731)\end{array}$ & $\begin{array}{c}8.089 \\
(7.838)\end{array}$ & $\begin{array}{c}0.334 \\
(3.261)\end{array}$ & $\begin{array}{c}3.357 \\
(5.089)\end{array}$ & $\begin{array}{c}2.885 \\
(12.695)\end{array}$ & $\begin{array}{l}-46.002 \\
(90.671)\end{array}$ \\
\hline Alignment with State government & $\begin{array}{c}-360.299 * * \\
(173.262)\end{array}$ & $\begin{array}{c}-0.870 * * * \\
(0.303)\end{array}$ & $\begin{array}{c}0.050 \\
(0.762)\end{array}$ & $\begin{array}{c}-0.959 * * * \\
(0.304)\end{array}$ & $\begin{array}{c}-0.671^{* *} \\
(0.279)\end{array}$ & $\begin{array}{c}-10.981 \\
(9.778)\end{array}$ \\
\hline Alignment with Federal government & $\begin{array}{c}462.655^{* *} \\
(195.031)\end{array}$ & $\begin{array}{c}-1.287^{* *} \\
(0.603)\end{array}$ & $\begin{array}{l}-0.083 \\
(0.288)\end{array}$ & $\begin{array}{c}-1.090 * * * \\
(0.152)\end{array}$ & $\begin{array}{c}-0.820 * * * \\
(0.219)\end{array}$ & $\begin{array}{l}-3.818 \\
(6.000)\end{array}$ \\
\hline Total population & $\begin{array}{c}134.250 \\
(105.383)\end{array}$ & $\begin{array}{c}0.576 \\
(0.916)\end{array}$ & $\begin{array}{c}0.219 \\
(0.320)\end{array}$ & $\begin{array}{l}-0.304 \\
(0.454)\end{array}$ & $\begin{array}{l}-0.004 \\
(0.918)\end{array}$ & $\begin{array}{c}3.847 \\
(5.533)\end{array}$ \\
\hline Elderly & $\begin{array}{c}9763.903 \\
(7082.610)\end{array}$ & $\begin{array}{c}4.165 \\
(32.897)\end{array}$ & $\begin{array}{l}-10.551 \\
(16.138)\end{array}$ & $\begin{array}{c}-4.987 \\
(12.545)\end{array}$ & $\begin{array}{c}-7.683 \\
(11.909)\end{array}$ & $\begin{array}{c}107.501 \\
(154.373)\end{array}$ \\
\hline Young & $\begin{array}{c}1034.914 \\
(1170.614)\end{array}$ & $\begin{array}{c}8.441 \\
(5.162)\end{array}$ & $\begin{array}{l}-6.211^{*} \\
(3.211)\end{array}$ & $\begin{array}{c}1.734 \\
(2.795)\end{array}$ & $\begin{array}{l}-0.926 \\
(5.521)\end{array}$ & $\begin{array}{c}20.412 \\
(58.448)\end{array}$ \\
\hline Inverse Mills ratio & $\begin{array}{l}-215.713 \\
(225.397)\end{array}$ & $\begin{array}{l}-1.165 \\
(1.364)\end{array}$ & $\begin{array}{c}-0.564^{*} \\
(0.327)\end{array}$ & $\begin{array}{l}-0.147 \\
(0.433)\end{array}$ & $\begin{array}{l}-0.674 \\
(0.534)\end{array}$ & $\begin{array}{l}-3.492 \\
(5.296)\end{array}$ \\
\hline First lag of dependent variable & $\begin{array}{c}0.102^{* *} \\
(0.047)\end{array}$ & $\begin{array}{c}0.057 \\
(0.070)\end{array}$ & $\begin{array}{c}0.042 \\
(0.637)\end{array}$ & $\begin{array}{l}-0.551 \\
(0.479)\end{array}$ & $\begin{array}{c}0.060 \\
(0.652)\end{array}$ & $\begin{array}{c}-2.155^{*} \\
(1.160)\end{array}$ \\
\hline Constant & $\begin{array}{c}493.795 \\
(1260.477)\end{array}$ & $\begin{array}{c}-15.933^{* *} \\
(7.065)\end{array}$ & $\begin{array}{c}2.241 \\
(2.274)\end{array}$ & $\begin{array}{c}3.276 \\
(2.216)\end{array}$ & $\begin{array}{c}0.557 \\
(7.489)\end{array}$ & $\begin{array}{l}-19.163 \\
(40.107)\end{array}$ \\
\hline Observations $(\mathrm{NxT})$ & 27,144 & 27,144 & 27,144 & 27,144 & 27,144 & 27,144 \\
\hline $\begin{array}{l}\text { Instruments for differenced equation } \\
\text { Instruments for level equation }\end{array}$ & $\begin{array}{l}\text { from } y_{i t-2} \text { to } y_{i t-4} \\
\qquad \Delta y_{i t-3}\end{array}$ & $\begin{array}{c}y_{i t-2} \\
\Delta y_{i t-5}\end{array}$ & $\begin{array}{c}y_{i t-2} \\
\Delta y_{i t-5}\end{array}$ & $\begin{array}{c}y_{i t-2} \\
\Delta y_{i t-3}\end{array}$ & $\begin{array}{c}y_{i t-2} \\
\Delta y_{i t-3}\end{array}$ & $\begin{array}{c}y_{i t-3} \\
\Delta y_{i t-5}\end{array}$ \\
\hline Sargan (p-value) & 0.498 & 0.160 & 0.517 & 0.668 & 0.473 & 0.849 \\
\hline$m_{1}(\mathrm{p}$-value $)$ & 0.000 & 0.590 & 0.260 & 0.081 & 0.433 & 0.402 \\
\hline$m_{2}(\mathrm{p}$-value $)$ & 0.149 & 0.693 & 0.418 & 0.140 & 0.685 & 0.179 \\
\hline
\end{tabular}

Source: Own authors

Notes: *** Significant at 1\%; ** Significant at 5\%; * Significant at 10\%; Windmeijer (2005) Robust standard errors in parenthesis; Sargan is a test for valid instruments under the null hypothesis, asymptotically distributed as $\chi^{2}$, with degrees of freedom equal to the number of over-identifying restrictions. $m_{1}$ and $m_{2}$ are tests for first and second-order serial correlation in the first-differenced residuals, asymptotically distributed as $\mathrm{N}(0,1)$ under the null hypothesis of no serial correlation. 
Equation 1 and ran it again, but now comparing first term mayors who run for reelection to mayors in their second and last term (TERM $=1$ if the mayor runs for reelection and 0 if he is in second term). According to the estimations presented in Table 4, one can observe that, except for the case of total expenditures, the parameter regarding the Inverse Mills Ratio lacks statistical significance, i.e. there is no evidence of selectivity bias ${ }^{20}$.

Compared to the results from Table 2 , the results in Table 4 remain practically unchanged, except for one important difference: average total expenditures over the term (non-electoral years) are higher under first term mayors who run for reelection. In fact, as the inverse Mills ratio indicated, the amount of total expenditures and the decision to run for reelection are closely related ${ }^{21}$. All other results point to the same conclusion: first term mayors who run for reelection act opportunistically by reducing both local taxes and current expenditures and increasing capital investments in a fiscally responsible manner, as budget balances and total expenditures remain unchanged during elections. These figures confirm our initial proposals: given the current institutional setting in Brazil, a greater degree of fiscal opportunism in capital investments was to be observed relatively to current and personnel expenditures (refer to discussion in section 3).

In summary, we find that first term mayors and reelection runners, relative to second term mayors, reduce tax revenues and move fiscal policy away from current expenditures towards capital investments in electoral years. This movement appears strange at first, since by employing this strategy, first term mayors direct fiscal policy away from the budget "heavy weights" accounts (such as current expenditures) towards smaller accounting rubrics (such as capital investments). However, the decision to switch the composition of spending from less visible (and more burdensome) expenditures to more visible (and fiscally sustainable) ones is consistent with a politician whose objective function is to maximize his probability of reelection subject to institutional constraints on fiscal management. Such fiscal movement is even more relevant if we assume that voters are fiscal conservatives and evaluate incumbents mostly by observing visible public policies and services, especially during elections(i.e. voters are short sighted) 2 .

One potential caveat in the study refers to the role of competence. Second term mayors can be considered especially competent incumbent types, as they survived previous elections and were reelected by voters. Besides, their longer tenure in local office endows them with more experience of the administrative and fiscal situation of the municipality. Are our findings affected by competence differences between first and second term mayors? We believe not. If competent incumbents are those who deliver the most preferred public services (highly visible and welfare improving expenditures) at the lowest costs (lower taxes) and with the least negative externalities (lower deficits), then our results should present significant differences for the First Term Mayor dummy, as it captures differences in the term's average fiscal variable (non-electoral years) between first term and second term mayors. This was not the case. In fact, fiscal differences between first and final term mayors were mostly observed during elections. The reason is simple: it is precisely during elections that the need to signal competence and be accountable to voters becomes stronger. Mayors in their second and final term, although proven to be competent, lack the accountability incentives related to reelection and do not need to signal competence or build a positive reputation for a next mandate. As a result, the fiscal policies carried out by last term mayors in the last years of their second mandate should not deviate much from those followed throughout their term, or at least not as much as those of first

and calculated the Inverse Mills Ratio at this value.

${ }^{20}$ Similarly to Table 2 the estimations comply with both Sargan and $m_{2}$ tests for dynamic panel data.

${ }^{21}$ This somehow echoes the findings in Sakurai \& Menezes Filho (2008), for whom higher total spending over the term increases the mayor's party reelection probability.

${ }^{22}$ The literature is still inconclusive about whether Brazilian voters are fiscal conservatives or fiscal liberals. Arvate, Avelino \& Tavares (2009) suggest that voters do not like deficits in general at the state level. Sakurai \& Menezes Filho (2008) show that voters enjoy higher total spending at the local level, but do not test their reaction to deficits. Theoretically, local voters in the Brazilian fiscal federalism should act as fiscal liberals (Jones, Meloni \& Tommasi (2012)). 
term mayors. Our estimates suggest that electoral cycles are stronger under first term mayors and reelection runners. We believe this finding matches the theoretical predictions of higher accountability effects of elections for incumbents who are not limited to stand for another term in office23.

\section{Concluding remarks}

This article tested the effects of term limits on opportunistic political budget cycles (PBC) in municipal elections in Brazil, by comparing differences in the fiscal behaviour of first term mayors (who are allowed to run for a second mandate) and second term mayors (who are prohibited to run for reelection) during electoral years.

Based on fiscal and electoral data of 3,393 Brazilian municipalities between 2001 and 2008, this research has provided strong evidence in favour of significant electoral fiscal differences between first term and second term mayors. As elections draw close, first term mayors reduce local taxes and change their budget composition by reducing current expenditures and increasing capital investments. Importantly, they seem to do so in a fiscally responsible manner, as budget balances and total expenditures remain unchanged during elections. The results also indicate that the average fiscal performance delivered by first term mayors during non-electoral years does not significantly differ from those of final term mayors. In this sense, different levels of competence between first and final term mayors do not seem to have any specific effect on the fiscal choices implemented throughout their terms in office. In fact, fiscal differences between both types of mayors are mostly restricted to electoral periods, a time when the accountability and signalling effects of elections reach their peak. Finally, the results remained practically unchanged when we compared first term mayors who do in fact choose to run for reelection to second term mayors.

These findings are consistent with recently developed signalling models of PBC and with the conditional political budget cycles literature: incumbents aiming at maximizing their reelection chances subject to institutional restrictions on fiscal deficits seek to signal their competence levels or policy preferences by changing the composition of the budget in electoral years through the provision of more visible expenditures to rational and heterogeneous voters who may (or may not) be averse to higher spending in general, but have a preference for targeted expenditures(Drazen \& Eslava (2010)).

Our findings indicate that reducing term limitations - such as changing from a one-term term limit system to a two-terms term limit system, as Brazil did recently - is a welcome institutional mechanism for enhancing electoral accountability and improving voters' ability to select competent incumbents. The accountability and selection effects of reduced term limits seem to become even stronger when combined with other institutional limitations on fiscal profligacy. To better assess how these conditions affect electoral results, future studies should investigate whether voters respond positively to such opportunistically targeted, although fiscally responsible, electoral strategies.

Acknowledgements: The authors wish to thank participants at the 2013 Meeting of the European Public Choice Society, KOF ETH Zurich, Switzerland, 3rd-6th April, 2013. We also acknowledge the careful text revision provided by Natalie Skerritt. The second author would like to thank financial support provided by Fapesp and CNPq.

\section{References}

Aidt, Toke S. \& Julia Shvets. 2012. "Distributive politics and electoral incentives: Evidence from seven US state legislatures." American Economic Journal:Economic Policy 4(3):1-29.

\footnotetext{
${ }^{23}$ This is close to the ideas present in Alt, Mesquita \& Rose (2011). However, the authors focus on performance differences over the whole term rather than differences during elections.
} 
Aidt, Toke S., Francisco José Veiga \& Linda Gonçalves Veiga. 2010. "Election results and opportunistic policies: A new test of the rational political business cycle model." Public Choice 148(1-2):21-44.

Alesina, Alberto. 1987. "Macroeconomic policy in a two-party system as a repeated game." The Quarterly Journal of Economics 102(3):651-678.

Alesina, Alberto \& Nouriel Roubini. 1992. "Political Cycles in OECD Economies." The Review of Economic Studies 59(4):663-688.

Alesina, Alberto, Nouriel Roubini \& Gerald D. Cohen. 1997. Political cycles and the macroeconomy. MIT Press.

Alt, James E. \& David Dreyer Lassen. 2006. "Transparency, political polarization and political budget cycles in OECD countries." American Journal of Political Science 50(3):530-550.

Alt, James, Ethan Bueno de Mesquita \& Shanna Rose. 2011. "Disentangling accountability and competence in elections: evidence from U.S. term limits." The Journal of Politics 73(1):171-186.

Ames, Barry. 1987. Political survival: politicians and public policy in Latin America. University of California Press.

Arvate, Paulo Roberto, George Avelino \& José Tavares. 2009. "Fiscal conservatism in a new democracy: "sophisticated" versus "naive" voters." Economics Letters 102(2):125-127.

Barberia, Lorena Guadalupe \& George Avelino. 2011. "Do political budget cycles differ in Latin American democracies?" Journal of the Latin American and Caribbean Economic Association Economia 11(2):101-146.

Beck, Nathaniel. 1982. "Parties, administrations, and American macroeconomic outcomes." The American Political Science Review 76(1):83-93.

Berry, Christopher R., Barry C. Burden \& William G. Howell. 2010. "The president and the distribution of federal spending." American Political Science Review 104(4):783-799.

Besley, Timothy \& Anne Case. 1995. "Does political accountability affect economic policy choices? Evidence from gubernatorial term limits." The Quarterly Journal of Economics 110(3):769-798.

Blundell, Richard \& Stephen Bond. 1998. "Initial conditions and moment restrictions in dynamic panel data models." Journal of Econometrics 87:115-143.

Brender, Adi. 2003. "The effect of fiscal performance on local government election results in Israel: 1989-1998." Journal of Public Economics 87:2187-2205.

Brender, Adi \& Allan Drazen. 2008. "How do budget deficits and economic growth affect reelection prospects? Evidence from a large panel of countries." The American Economic Review 98(5):22032220.

Brender, Adi \& Allan Drazen. 2005. "Political budget cycles in new versus established democracies." Journal of Monetary Economics 52:1271-1295.

Castro, Vitor \& Rodrigo Martins. 2013. "Running for office again: evidence from Portuguese municipal elections." Public Choice 156(3-4):677-702.

De Haan, Jakob \& Jeroen Klomp. 2013a. "Conditional political budget cycles: a review of recent evidence." Public Choice 157(3-4):387-410.

De Haan, Jakob \& Jeroen Klomp. 2013b. "Political budget cycles and election outcomes." Public Choice 157(1-2):245-267.

Drazen, Allan \& Marcela Eslava. 2010. "Electoral manipulation via voter-friendly spending: Theory and evidence." Journal of Development Economics 92:39-52.

Fair, Ray C. 1978. "The effect of economic events on votes for president." The Review of Economics and Statistics 60(2):159-173.

Ferraz, Cláudio \& Frederico Finan. 2011. "Electoral accountability and corruption: evidence from the audits of local governments." American Economic Review 101(4):1274-1311.

Ferreira, Ivan F. S. \& Mauricio S. Bugarin. 2007. "Transferências Voluntárias e Ciclo PolíticoOrçamentário no Federalismo Fiscal Brasileiro." Revista Brasileira de Economia 61(3):271-300.

Franzese, Robert J. \& Karen Long Jusko. 2008. "Political-Economic Cycles."In The Oxford Handbook of Political Economy, ed. B.R.Weingast and D.A. Wittman,545-564. Oxford University Press.

Frey, Bruno S. \& Friedrich Schneider. 1978a. "An empirical study of politico-economic interaction in the United States." The Review of Economic and Statistics 60(2):174-183.

Frey, Bruno S. \& Friedrich Schneider. 1978b. "A politico-economic model of the United Kingdom." The Economic Journal 88(350):243-253. 
Heckman, James J. 1979. "Sample Selection Bias as a Specification Error." Econometrica 47(1):153161.

Hibbs Jr., Douglas A. 1977. "Political parties and macroeconomic policy." The American Political Science Review 71(4):1467-1487.

Jones, Mark. P., Osvaldo Meloni \& Mariano Tommasi. 2012. "Voters as fiscal liberals: incentives and accountability in federal systems." Economics \& Politics 24(2):135-156.

Johnson, Joseph M. \& W. Mark Crain. 2004. "Effects of term limits on fiscal performance: Evidence from democratic nations." Public Choice 119:73-90.

Kramer, Gerald H. 1971. "Short-Term Fluctuations in U.S. Voting Behavior, 1896-1964." The American Political Science Review 65(1):131-143.

Larcinese, Valentino, Leonzio Rizzo \& Cecilia Testa. 2006. "Allocating the U.S. Federal Budget to the States: The Impact of the President." Journal of Politics 68(2):447-456.

Lema, Daniel \& Jorge M. Streb. 2013. "Party alignment and political budget cycles: the Argentine provinces." Universidad Del Cema Documentos de Trabajo No 520.

Lindbeck, Assar. 1976. "Stabilization Policy in Open Economies with Endogenous Politicians." The American Economic Review 66(2):1-19.

List, John A. \& Daniel M. Sturm. 2006. "How elections matter: theory and evidence from environmental policy." The Quarterly Journal of Economics 121(4):1249-1281.

Meneguin, Fernando B. \& Maurício Soares Bugarin. 2001. "Reeleição e política fiscal: um estudo dos efeitos nos gastos públicos." Economia Aplicada 5(3):600-622.

Mizuca, Humberto Dantas de. 2007. Coligações em eleições majoritárias municipais: a lógica do alinhamento dos partidos políticos brasileiros nas disputas de 2000 e 2004. PhD thesis Departamento de Ciência Política - Faculdade de Filosofia, Letras e Ciências Humanas - Universidade de São Paulo.

Nakaguma, Marcos Yamada \& Siegfried Bender. 2006. "A emenda da reeleição e a Lei de Responsabilidade Fiscal: impactos sobre ciclos políticos e performance fiscal dos estados (1986-2002)." Economia Aplicada 10(3):377-397.

Nogare, Chiara Dalle \& Rober Ricciuti. 2011. "Do term limits affect fiscal policy choices?" European Journal of Political Economy 27(11):681-692.

Nordhaus, William D. 1975. "The political business cycle." The Review of Economic Studies 42(2):169-190.

Peltzman, Sam. 1992. "Voters as fiscal conservatives." The Quarterly Journal of Economics 107(2):327-361.

Porto, Alberto \& Natalia Porto. 2000. "Fiscal Decentralization and Voters' Choices as Control." Journal of Applied Economics 3:135-167.

Rodrigues, Leôncio Martins. 2002. Partidos, ideologia e composição social: um estudo das bancadas partidárias na Câmara dos Deputados. Edusp.

Rogoff, Keneth \& Anne Sibert. 1988. "Elections and macroeconomic policy cycles." The Review of Economic Studies 55(1):1-16.

Rogoff, Kenneth. 1990. "Equilibrium political budget cycles." The American Economic Review $80(1): 21-36$.

Rose, Shann. 2006. "Do fiscal rules dampen the political business cycle?" Public Choice 128(34):407-431.

Rosenberg, Jacob. 1992. "Rationality and the political business cycle: The case of local government." Public Choice 73(1):71-81.

Rumi, Cecilia. 2008. "National electoral cycles in transfers to subnational jurisdictions. Evidence from Argentina." In Finanzas públicas bajo competencia política. Marco federal y evidencia de Argentina, Rumi, Cecilia. Editorial de la Universidad Nacional de la Plata.

Sakurai, Sergio Naruhiko \& Naércio Aquino Menezes Filho. 2008. "Fiscal policy and reelection in Brazilian municipalities." Public Choice 137(1-2):301-314.

Sakurai, Sergio Naruhiko \& Naércio Aquino Menezes Filho. 2011. "Opportunistic and partisan election cycles in Brazil: new evidence at the municipal level." Public Choice 148(1-2):233-247.

Schneider, Cristina J. 2010. "Fighting with one hand tied behind the back: political budget cycles in the West German states." Public Choice 142(1-2):125-150.

Sheffrin, Steven M. 1989. "Evaluating rational partisan business cycle theory." Economics $E$ Politics 1(3):239-259. 
Shi, Min \& Jakob Svensson. 2006. "Political budget cycles: Do they differ across countries and why?" Journal of Public Economics 90(8-9):1367-1389.

Smart, Michael \& Daniel M. Sturm. 2006. "Term limits and electoral accountability." LSE CEP Discussion Paper No 770.

Streb, Jorge M., Daniel Lema \& Gustavo Torrens. 2009. "Checks and Balances on Political Budget Cycles: Cross-Country Evidence." Kyklos 62(3):426-447.

Tufte, Edward R. 1975. "Determinants of the Outcomes of Midterm Congressional Elections." The American Political Science Review 69(3):812-826.

Tufte, Edward R. 1978. Political control of the economy. Princeton University Press.

Veiga, Francisco José \& Linda Gonçalves Veiga. 2007. "Political business cycles at the municipal level." Public Choice 131:45-64.

Vergne, Clémence. 2009. "Democracy, elections and allocation of public expenditures in developing countries." European Journal of Political Economy 25:63-77.

Windmeijer, Frank. 2005. "A finite sample correction for the variance of linear efficient two-step GMM estimators." Journal of Econometrics 126:25-51.

\section{A Appendix}

Table A.1: Descriptive statistics

\begin{tabular}{lcr}
\hline \multicolumn{1}{c}{ Variable } & Mean & Standard deviaton \\
\hline Budget balance (per capita) & 33.28 & 112.40 \\
Tax revenues (per capita) & 82.75 & 110.15 \\
Total expenditures (per capita) & $1,216.61$ & 676.88 \\
Current expenditures (per capita) & $1,048.75$ & 551.02 \\
Personnel expenditures (per capita) & 519.79 & 265.65 \\
Capital investments (per capita) & 145.33 & 172.83 \\
Current Transfers / Total Revenues & 0.83 & 0.11 \\
Current Transfers Grants (per capita - sum over the local mandate) & 77.14 & 101.07 \\
Capital Transfers Grants (per capita - sum over the local mandate) & 119.91 & 194.68 \\
Share of votes - State deputy & 0.12 & 0.07 \\
Share of votes - Federal Deputy & 0.13 & 0.09 \\
Fractionalization of votes & 0.52 & 0.12 \\
Alignment with State government & 0.24 & 0.42 \\
Alignment with Federal government & 0.10 & 0.30 \\
Left & 0.20 & 0.40 \\
Right & 0.41 & 0.49 \\
Elderly & 0.08 & 0.02 \\
Young & 0.29 & 0.05 \\
Total population & $39,769.84$ & $244,028.00$ \\
Age & 47.68 & 9.39 \\
University degree & 0.43 & 0.49 \\
Male & 0.94 & 0.24 \\
Public servant & 0.17 & 0.37 \\
\hline
\end{tabular}

Source: Own authors 